\title{
PERENCANAAN STRATEGI PEMASARAN MENGGUNAKAN ANALISIS SWOT DAN QSPM DALAM UPAYA PENINGKATAN PENJUALAN PT PRIMAVISTA SOLUSI
}

\author{
Oleh: \\ Widiyarini ${ }^{1}$ \\ Zeny Fatimah Hunusalela ${ }^{2}$
}

Mahasiswa Pasca Sarjana, Program Doktor Ilmu Ekonomi, Universitas Borobudur/Dosen Teknik Industri, Fakultas Teknik dan Ilmu Komputer, Universitas Indraprasta PGRI

Dosen Teknik Industri, Fakultas Teknik dan Ilmu Komputer, Universitas Indraprasta $P G R I^{2}$

Email:

widiya2513@gmail.com; zeny.fh86@gmail.com

\begin{abstract}
ABSTRAK
Persaingan dalam dunia bisnis mulai meningkat, baik bisnis yang bergerak dibidang manufaktur maupun jasa. Kemampuan perusahaan untuk unggul melawan kompetitornya akan menentukan perusahaan mana yang tetap menjadi pilihan pasar dan mana yang harus gulung tikar. PT PRIMAVISTA SOLUSI memerlukan manajemen strategi yang baik untuk dapat mencapai target yang telah ditentukan. Perumusan strategi yang sesuai untuk PT PRIMAVISTA SOLUSI dilakukan melalui tiga tahap, tahap pertama adalah tahap input menggunakan matriks EFE (External Factor Evaluation) dan matriks IFE (Internal Factor Evaluation). Tahap kedua adalah tahap pencocokan (matching stage) menggunakan matriks Grand Strategy dan matriks SWOT. Tahap ketiga adalah tahap keputusan (decision stage) menggunakan pendekatan Pairwise Comparison. Dari tahap pencocokan didapat 3 alternatif strategi, yaitu alternatif strategi penetrasi pasar, pengembangan pasar, dan pengembangan produk. 3 alternatif strategi tersebut dipilih bobotnya paling tinggi yaitu strategi pengembangan pasar dan pengembangan produkdengan score 0,4561 . Sehingga diharapkan dari rancangan strategi tersebut perusahaan dapat mencapai target penjualan yang telah ditentukan.
\end{abstract}

Kata kunci: Grand Strategy, SWOT, pairwise comparison 


\section{A. PENDAHULUAN}

Persaingan dalam dunia bisnis mulai meningkat, baik bisnis yang bergerak dibidang manufaktur maupun jasa. Kemampuan perusahaan untuk unggul melawan kompetitornya akan menentukan perusahaan mana yang tetap menjadi pilihan pasar dan mana yang harus gulung tikar. Lingkungan bisnis baik internal dan eksternal yang sangat dinamis dan kompleks semacam ini membutuhkan strategi bisnis yang tepat untuk mempertahankan eksistensi perusahaan. Kompleksitas ini akan berimplikasi pada proses pengambilan keputusan yang semakin sulit dan rumit. Untuk itulah manajemen strategi memegang peranan sentral. Setiap strategi selalu memerlukan peninjauan ulang dan bahkan mungkin perubahan dimasa depan. Salah satu alasan utama mengapa demikian halnya adalah karena kondisi yang dihadapi perusahaan baik internal maupun eksternal juga selalu berubah. Analisis dan pemilihan strategi merupakan salah satu langkah penting dalam manajemen strategi (David, 2009).

Penilaian yang dilakukan secara simultan terhadap lingkungan eksternal dan profil perusahaan memungkinkan manajemen mengidentifikasikan berbagai jenis peluang yang mungkin timbul dan dapat dimanfaatkan (Baroto \& Purbohadiningrat, 2014). Berbagai peluang tersebut berupa kemungkinan yang wajar untuk dipertimbangkan. Dalam melakukan analisis tentang berbagai kemungkinan tersebut manajemen mutlak perlu melakukan penyaringan yang cermat sehingga terlihat perbedaan nyata antara kemungkinan peluang dan kemungkinan yang diinginkan. Strategi yang handal, tepat dan jitu merupakan salah satu syarat bagi keberlangsungan kegiatan bisnis perusahaan. Untuk itu proses analisis dan pemilihan strategi menjadi salah satu kegiatan pokok bagi manajemen.

Manajemen strategi adalah suatu proses pengambilan keputusan dan tindakan yang mengarah kepada pengembangan strategi yang efektif atau yang membantu perusahaan mencapai tujuannya (Suci, 2009). Menurut (Ramadhan \& Sofiyah, 2008) juga mengatakan bahwa manajemen strategi merupakan suatu seni dan pengatahuan dalam merumuskan, mengimplementasikan, dan mengevaluasi keputusan-keputusan lintas fungsional yang memampukan sebuah organisasi mencapai tujuannya. Manajemen strategi bagi suatu perusahaan penting dalam rangka mencapai tujuan yang diinginkan, sehingga suatu perusahaan akan lebih maju. Jika suatu perusahaan tidak memiliki manajemen strategi yang sesuai dengan kondisi perusahaan dapat mengakibatkan apa yang diharapkan perusahaan tidak tercapai.

PT (Adnyana \& Darma, 2015)adalah perusahaan yang bergerak di bidang IT sebagai penyedia jasa end-to-end payment system untuk perbankan di Indonesia. Jasa yang disediakan oleh PT Primavista adalah jasa pengembangan aplikasi EDC (Electronic Data Capture), serta pengembangan aplikasi lain yang berkaitan dengan transaksi perbankan. Karena besarnya persaingan dalam bidang ini dan semakin banyaknya perusahaan sejenis yang menjadi competitor, PT Primavista memerlukan manajemen strategi yang baik. PT Primavista yang berupaya menjadi vendor EDC terbesar yang dapat melayani seluruh Bank di Indonesia perlu senantiasa mengevaluasi strategi perusahaan agar setiap tindakan yang dilaksanakan perusahaan dapat senantiasa ke arah pencapaian tujuan 
tersebut. Saat ini, PT Primavista Solusi telah menyebarkan lebih dari 100.000 perangkat pembayaran untuk 11 acquiring bank yang terhubung ke sistem debit nasional atau ATM switching yang menyediakan transaksi perbankan dan pembayaran tagihan melalui EDC untuk lebih dari 40 bank di Indonesia. PT Primavista Solusi memiliki target yang harus dapat dicapai tiap tahunnya, target ini terus meningkat setiap tahun. Target yang harus dicapai adalah total pemasukan tahunan perusahaan dari hasil penjualan produk. Pencapaian PT Primavista Solusi di tahun 2017 adalah sebesar IDR 40 milyar. Sedangkan target yang harus dicapai tahun 2018 sebesar IDR 45 milyar. Target tersebut merupakan total penjualan yang harus tercapai sampai akhir tahun. Dengan makin banyaknya perusahaan sejenis yang menyediakan jasa payment solution, persaingan di dunia bisnis ini pun semakin tinggi. Berdasarkan permasalahan tersebut, perusahaan memerlukan evaluasi strategi untuk menyesuaikan dengan keadaan lingkungan. Lingkungan dalam dan luar perusahaan dapat menjadi faktor penyebab kemajuan maupun kegagalan perusahaan oleh karena itu diperlukan strategi bisnis dengan menggunakan analisis SWOT untuk mengetahui kekuatan, kekurangan, ancaman dan peluang pada perusahaan (Effendi, Setyorini, \& Santoso, 2016). Dari hasil SWOT nantinya akan dilakukan prioritas strategi perbaikan dengan menggunakan QSPM (Febrianti \& K, 2014). Oleh karena itu, penelitian ini mencoba merumuskan strategi yang sesuai untuk perusahaan dengan keadaan saat ini agar dapat mencapai target yang diinginkan.

\section{B. KAJIAN PUSTAKA}

\section{Pengertian Manajemen Strategi}

Manajemen strategi dapat didefinisikan sebagai seni dan pengetahuan dalam merumuskan, mengimplementasikan, serta mengevaluasi keputusan-keputusan lintas fungsional yang memungkinkan perusahaan dapat mencapai tujuannya. Secara tersirat, manajemen strategi berfokus pada mengintegrasikan manajemen, pemasaran, keuangan/akuntansi, produksi/operasional, penelitian dan pengembangan, serta sistem informasi komputer untuk mencapai tujuan organisasi. Manajemen strategi merupakan langkah awal perusahaan bergerak. Artinya seluruh kegiatan perusahaan bergantung pada perencanaan strategis yang dirumuskan. Oleh karena itu, perusahaan yang merumuskan strategi yang tepat dan mampu menerapkannya dalam kegiatan perusahaan dapat mencapai kesuksesan (Andreani, 2007).

Tujuan manajemen strategis adalah untuk mengeksploitasi serta menciptakan berbagai peluang baru dan berbeda untuk masa depan (perencanaan jangka panjang), sebaliknya mencoba untuk mengoptimalkan tren sekarang untuk masa depan.

\section{Tahap-tahap Manajemen Strategi}

Proses manajemen strategi terdiri atas tiga tahap (Suci, 2009), antara lain:

a. Perumusan Strategi

Perumusan strategi mencakup pengembangan visi dan misi, identifikasi peluang dan ancaman eksternal suatu organisasi, kesadaran akan kekuatan 
dan kelemahan internal, penetapan tujuan jangka panjang, pencarian strategistrategi alternatif, dan pemilihan strategi tertentu untuk mencapai tujuan.

b. Penerapan Strategi

Penerapan strategi mengharuskan perusahaan untuk menetapkan tujuan tahunan, membuat kebijakan, memotivasi karyawan, dan mengalokasikan sumber daya, sehingga strategi-strategi yang telah dirumuskan dapat dijalankan.

c. Penilaian Strategi

Penilaian strategi merupakan tahap terakhir dalam manajemen strategis. Tiga aktivitas penilaian strategi yang mendasar adalah peninjauan ulang faktorfaktor eksternal dan internal yang menjadi landasan bagi strategi saat ini, pengukuran kinerja, dan pengambilan langkah korektif.

\section{Analisis SWOT}

Analisis SWOT adalah evaluasi tentang kekuatan, kelemahan,peluang dan ancaman perusahaan dan merupakan cara untuk mengamati lingkungan pemasaran eksternal dan internal (Baroto \& Purbohadiningrat, 2014).

Analisa ini didasarkan pada logika yang dapat memaksimalkan kekuatan (strength) dan peluang (opportunities) namun secara bersamaan dapat meminimalkan kelemahan (weaknesses) dan ancaman (threats). Peneliti menunjukan bahwa kinerja perusahaan dapat ditentukan oleh kombinasi faktor internal dan eksternal. Kedua faktor tersebut harus dipertimbangkan alam analisis SWOT. SWOT adalah ingkatan dari lingkungan Internal Strengths dan Weaknesses serta lingkungan ekternal Opportunities dan Threats yang dihadapidunia bisnis. Analisis SWOT membandingkan antara faktor eksternal Peluang (opportunities) dan ancaman (threats) dengan faktor internal kekutan (strengths) dan kelemahan (weaknesses) (Putri, Astuti, \& Putri, 2016).

\section{Analisis QSPM}

QSPM (Quantitative Strategic Planning Matrix) merupakan suatu teknik untuk mengidentifikasi alternatif strategi yang sesuai atau terbaik bagi kondisi perusahaan (Widianti \& Damayanti, 2015). QSPM memiliki beberapa kelebihan seperti serangkaian strateginya dapat diamati secara berurutan atau bersamaan, membutuhkan para penyusun strategi untuk mengintegrasikan faktor-faktor eksternal dan internal yang relevan ke dalam proses pengambilan keputusan, menggarisbawahi hubungan-hubungan penting yang dapat mempengaruhi keputusan-keputusan strategi, meningkatkan probabilitas diperolehnya keputusan strategis akhir yang terbaik bagi organisasi (Suci, 2009). Untuk mengetahuinya diperlukan suatu perbandingan berpasangan, dimana setiap alternatif strategi akan dipasangkan dengan menggunakan kuesioner skala 1-9 ((Febrianti \& K, 2014). Skala tingkat kepentingan dapat dilihat pada Tabel 1. 
Tabel 1. Tingkat Kepentingan Skala 1-9

\begin{tabular}{cl}
\hline Skala & \multicolumn{1}{c}{ Keterangan } \\
\hline 1 & Faktor vertikal sama penting dengan faktor horizontal \\
3 & Faktor vertikal lebih penting dengan faktor horizontal \\
5 & Faktor vertikal jelas lebih penting dengan faktor horizontal \\
7 & Faktor vertikal sangat jelas lebih penting dengan faktor horizontal \\
9 & Faktor vertikal mutlak lebih penting dengan faktor horizontal \\
$2,4,6,8$ & Apabila ragu-ragu antara dua elemen yang berdekatan \\
$1 /(2-9)$ & Kebalikan keterangan nilai 2-9 \\
\hline
\end{tabular}

Setelah mendapatkan hasil kuesioner perbandingan berpasangan skala 1-9, dibuat matriks perbandingan berpasangan. Dalam penilaian kepentingan relatif dua elemen berlaku aksioma reciprocal. hasil tersebut dilakukan perhitungan matematis untuk mendapatkan nilai bobot dan nilai konsistensi. Adapun langkahlangkah perhitungannya sebagai berikut:

\section{Geometrik}

Langkah ini digunakan untuk mengolah data dari 1 responden ahli. Adapun rumus dari langkah ini adalah:

$$
G=\sqrt{\prod X_{i}}
$$

Dimana:

$\mathrm{n}=$ jumlah responden

$\mathrm{X}_{i}=$ penilaian oleh responden $\mathrm{ke}-\mathrm{i}$

$\Pi=$ perkalian

2. Bobot

$$
\text { Bobot }=\frac{\text { Geometrik }}{\text { Total Geometrik }}
$$

Selanjutnya, yang perlu dilakukan adalah mencari nilai konsistensi. Hal ini untuk mengetahui apakah penilaian perbandingan berpasangan sudah konsisten. Jika nilai rasio konsistensi lebih dari 0.10 , penilaian perbandingan berpasangan harus diulang karena tidak konsisten. Untuk mendapatkan rasio konsistensi, pertama-tama mencari nilai weighted sum vektor dengan cara mengalikan angka bobot dengan matriks perbandingan berpasangan.

\section{Consistency Vector.}

Hal ini dapat dilakukan dengan cara membagi nilai weighted sum vector dengan nilai bobot yang telah didapatkan sebelumnya. Selanjutnya adalah menghitung nilai lambda $(\lambda)$ dan Consistency Index (CI). Nilai lambda merupakan nilai rata-rata consistency vector, dimana n merupakan jumlah alternatif strategi yang sedang dibandingkan. Sehingga didapat: 


$$
\mathbf{C I}=\frac{\lambda-\mathbf{n}}{\mathbf{n}-\mathbf{1}}
$$

Setelah didapat lambda dan indeks konsistensi, barulah dapat dihitung nilai rasio konsistensinya. Consistency Ratio (CR) sama dengan Consistency Index dibagi dengan Random Index (RI), dimana RI ditentukan berdasarkan pada sebuah Tabel RI. Random Index adalah sebuah fungsi langsung dari jumlah alternatif atau sistem yang sedang dipertimbangkan.

$$
\mathbf{C R}=\frac{C I}{R I}
$$

Consistency ratio tersebut mengindikasikan tingkat konsistensi pengambil keputusan dalam melakukan perbandingan berpasangan yang pada akhirnya mengindikasikan kualitas keputusan atau pilihan strategi yang akan diambil. Nilai CR yang besar menunjukkan kurang konsistennya hasil perbandingan berpasangan, sementara nilai CR yang semakin rendah mengindikasikan semakin konsistennya perbandingan yang dilakukan. Jika CR kurang atau sama dengan 0.10 , perbandingan yang dilakukan oleh pengambil keputusan termasuk nilai dari hasil perbandingan untuk dasar pengambilan keputusan secara relatif bisa dikatakan konsisten.

\section{METODE PENELITIAN}

Obyek penelitian adalah PT Primavista Solusi yang beralamat di Gedung Graha Pratama Lantai 19, Jl. MT. Haryono Kav. 15 Jakarta Selatan. yang dilakukan pada bulan Oktober 2018. Tahap metodologi penelitian adalah sebagai berikut:

1. Studi Pendahuluan

Dari studi pendahuluan dikaji mengenai pentingnya manajeman strategi perusahaan dalam mencapai tujuan perusahaan. Dilakukan tinjauan pendahuluan untuk mengetahui kemungkinan memilih PT Primavista Solusi sebagai obyek studi kasus serta mengapa harus dikembangkan strategi perusahaan untuk PT Primavista Solusi.

2. Perumusan Masalah

Perumusan masalah merupakan pertanyaan mengenai ruang lingkup permasalahan yang diteliti berdasarkan studi literatur yang dilakukan. Sebagaimana telah diuraikan sebelumnya, permasalahan diidentifikasikan dalam rangka merumuskan strategi perusahaan yang cocok untuk PT Primavista Solusi.

3. Penentuan Tujuan Penelitian

Menetapkan tujuan penelitian sebagai jawaban atas masalah yang telah diidentifikasi dalam rumusan masalah. Penetapan tujuan penelitian yang tepat dan eksplisit membantu peneliti dalam melakukan penyelesaian permasalahan secara akurat dan sistematis (Yin, 1996). Penetapan tujuan ini untuk menjawab pertanyaan penelitian yang dirumuskan pada tahap 
sebelumnya, dengan maksud untuk menentukan dan memastikan arah yang ingin dicapai pada penelitian ini (Bungin, 2007).

4. Studi Literatur

Pada tahap ini dilakukan studi pustaka untuk memperoleh dasar dan acuan teoritis dalam pencapaian tujuan penelitian yang telah ditetapkan sebelumnya. Informasi ini diperoleh dari berbagai literatur yang berhubungan dengan topik penelitian dan menjadi landasan teori bagi penelitian ini.

5. Pengumpulan Data

Pengumpulan data dibagi menjadi dua bagian, yaitu data primer dan data sekunder. Data primer didapat dari penyebaran kuesioner dengan identifikasi faktor-faktor eksternal dan internal perusahaan untuk dicari bobot, peringkat, dan skor. Kuesioner penelitian ini diberikan kepada masing-masing kepala divisi perusahaan, terdiri dari 4 responden, yaitu Kepala Technical Division, Kepala Commercial Division, Kepala Operations Division, dan Kepala General Administration. Faktor eksternal merupakan peluang dan ancaman bagi perusahaan yang datang dari luar perusahaan. Faktor-faktor eksternal dapat berupa : aspek ekonomi; aspek demografi, lingkungan, budaya, sosial ; aspek teknologi ; aspek kompetitif ; aspek hukum. Faktor-faktor eksternal yang menjadi peluang dan ancaman perusahaan yang didapat dari hasil kusioner pendahuluan Sedangkan data sekunder didapat dari perusahaan seperti sejarah perusahaan, nilai-nilai perusahaan, ambisi perusahaan, visi dan misi perusahaan, produk-produk yang dijual, dan data-data lainnya yang berhubungan dengan perusahaan. Data sekunder juga didapat dari referensi-referensi, baik dari buku maupun website.

6. Pengolahan Data

Mengolah data yang didapat dari tahap sebelumnya dengan menggunakan metode yang telah dipelajari pada studi literatur.Pengolahan data dilakukan dengan tiga tahap, yaitu tahap input, tahap pencocokan, dan tahap keputusan.

Tahap input dilakukan dengan memberikan bobot, peringkat, dan skor bobot untuk Matriks Evaluasi Faktor Eksternal (EFE), dan Matriks Evaluasi Faktor Internal (IFE).

Tahap pencocokan dilakukan dengan dua teknik, yaitu Matriks Kekuatan-Kelemahan-Peluang-Ancaman (SWOT Matrix), dan Matriks Strategi Besar (Grand Strategy Matrix). Setiap teknik ini akan memberikan strategi-strategi yang nantinya akan dipilih yang sesuai dengan kondisi perusahaan.

Untuk memilih strategi dari tahap pencocokan tersebut, dilakukan tahap keputusan dengan menggunakan pendekatan Pairwise Comparison.

7. Analisa dan Perumusan Strategi 
Setelah pengolahan data dilakukan, dilakukan analisa perumusan strategi terhadap strategi yang terpilih. Kemudian dijelaskan alasan strategi tersebut dipilih untuk diterapkan di perusahaan.

8. Kesimpulan dan Saran

Tahap terakhir penelitian ini adalah pengambilan kesimpulan sebagai jawaban atas tujuan penelitian yang telah dilakukan. Pada bagian saran diberikan upaya yang perlu dilakukan untuk kemajuan perusahaan.

\section{HASIL DAN PEMBAHASAN}

\section{Tahap Input}

\section{Matriks EFE}

Berdasarkan hasil perhitungan bobot dan rating faktor eksternal, dihitunglah score untuk matriks EFE. Score matriks EFE diperlihatkan pada Tabel 1. Score didapat dengan mengalikan bobot dengan rating. Hasilnya berupa score pembobotan untuk masing-masing faktor yang nilainya mulai dari 1.0 (poor) sampai dengan 4.0 (outstanding). Total score 4.0 mengindikasikan bahwa perusahaan merespon peluang dengan cara luar biasa dan menghindari ancamanancaman di pasar industri. Angka rata-rata nilai adalah 2.5. Total score 1.0 menunjukkan strategi-strategi perusahaan tidak memanfaatkan peluang-peluang atau tidak menghindari ancaman-ancaman eksternal. Selanjutnya, menjumlahkan score pembobotan untuk memperoleh total score bagi perusahaan.

Tabel 1. Score Matriks EFE

\begin{tabular}{|c|c|c|c|c|}
\hline \multirow{2}{*}{ NO } & FAKTOR - FAKTOR EKSTERNAL & \multirow{2}{*}{ ВОВОТ } & \multirow{2}{*}{ RATING } & \multirow{2}{*}{ SCORE } \\
\hline & PELUANG (OPPORTUNITY) & & & \\
\hline 1 & Bisnis payment solution yang sedang tumbuh dan akan terus tumbuh & 0.177 & 3.5 & 0.620 \\
\hline 2 & Kebutuhan masyarakat terhadap pembayaran cashless & 0.177 & 3.5 & 0.620 \\
\hline \multirow[t]{2}{*}{3} & Teknologi yang terus berkembang & 0.177 & 3.5 & 0.620 \\
\hline & TOTAL & & & 1.860 \\
\hline \multicolumn{5}{|c|}{ ANCAMAN (THREAT) } \\
\hline 1 & Pesaing yang bergerak dibidang yang sama & 0.190 & 3.5 & 0.665 \\
\hline 2 & Regulasi pemerintah (pajak, bea cukai, dsb) & 0.127 & 2.25 & 0.286 \\
\hline 3 & Bencana alam & 0.076 & 2.0 & 0.152 \\
\hline \multirow[t]{2}{*}{4} & Krisis ekonomi & 0.076 & 2.0 & 0.152 \\
\hline & TOTAL & & & 1.255 \\
\hline
\end{tabular}

Berdasarkan Tabel diatas, dapat dilihat bahwa peringkat semua faktor peluang sama besarnya. Hal ini menandakan perusahaan merespon ketiga peluang tersebut dengan cara yang sama. Ketiga peluang ini harus dipergunakan sebaik mungkin untuk kemajuan PT. Primavista Solusi. Sedangkan peringkat tertinggi untuk faktor ancaman yaitu pesaing yang bergerak dibidang yang sama. Ancaman ini mendapat respon paling tinggi dibandingkan ancaman yang lain. Ancaman ini harus dihindari oleh PT. Primavista Solusi apabila jika tidak ingin mengalami kegagalan. 


\section{Matriks IFE}

Berdasarkan hasil perhitungan bobot dan rating faktor internal, dihitunglah score untuk matriks IFE. Score matriks IFE diperlihatkan pada Tabel 2. Score matriks didapat dengan mengalikan bobot dengan rating. Hasilnya berupa score pembobotan untuk masing-masing faktor yang nilainya berada di antara 1.0 (low) dan 4.0 (high) dengan average score 2.5. Total score di bawah 2.5 mengindikasikan organisasi lemah secara internal, total score di atas 2.5 mengindikasikan organisasi kuat secara internal. Selanjutnya, menjumlahkan score pembobotan untuk memperoleh total score bagi perusahaan (Rangkuti, 2009)

Tabel 2. Score Matriks IFE

\begin{tabular}{|c|l|c|cc|}
\hline \multirow{2}{*}{ NO } & \multicolumn{1}{|c|}{ FAKTOR - FAKTOR INTERNAL } & \multirow{2}{*}{ BOBOT } & RATING & \multirow{2}{*}{ SCORE } \\
\cline { 2 - 3 } & \multicolumn{1}{|c|}{ KCKAN (STRENGTH) } & 0.056 & 3.75 & 0.21 \\
2 & Kemampuan karyawan mengembangkan produk & 0.049 & 3.5 & 0.171 \\
3 & Pengetahuan karyawan terhadap produk yang dijual & 0.06 & 4.0 & 0.24 \\
4 & Motivasi karyawan & 0.056 & 4.0 & 0.224 \\
5 & Kroduktivitas karyawan & 0.049 & 3.5 & 0.171 \\
6 & Ambisi perusahaan & 0.045 & 3.25 & 0.146 \\
7 & Pengembangan solusi in-house & 0.049 & 3.5 & 0.171 \\
8 & Produk-produk yang ditawarkan oleh perusahaan & 0.052 & 3.75 & 0.195 \\
9 & Rate bisnis yang bersaing dengan kompetitor & 0.045 & 3.5 & 0.158 \\
10 & Lokasi servis di kota-kota di Indonesia & 0.052 & 3.75 & 0.195 \\
& $\quad$ TOTAL & & & $\mathbf{1 . 8 8 1}$ \\
& $\quad$ KELEMAHAN (WEAKNESS) & & & \\
\hline 1 & Jumlah Sumber Daya Manusia (karyawan) & 0.06 & 1.25 & 0.075 \\
2 & Kualitas servis yang diberikan kepada pelanggan & 0.056 & 1.5 & 0.084 \\
3 & Kualitas aplikasi yang dihasilkan & 0.056 & 1.5 & 0.084 \\
4 & Customized solution & 0.045 & 2.0 & 0.09 \\
5 & Kesejahteraan karyawan & 0.052 & 1.75 & 0.091 \\
6 & Kelengkapan peralatan operasional untuk karyawan & 0.056 & 1.5 & 0.084 \\
7 & Sistem manajemen perusahaan & 0.056 & 1.5 & 0.084 \\
8 & Komunikasi antar divisi & 0.056 & 1.5 & 0.084 \\
9 & Sistem dokumentasi produk & 0.049 & 2.0 & 0.098 \\
& $\quad$ & & $\mathbf{0 . 7 7 4}$ \\
\hline
\end{tabular}

Berdasarkan Tabel 2, dapat dilihat bahwa peringkat kekuatan tertinggi berada pada S3 dan S4, yaitu motivasi karyawan dan produktivitas karyawan. Kekuatan ini harus dipergunakan sebaik mungkin untuk kemajuan PT. Primavista Solusi. Sedangkan peringkat tertinggi untuk faktor kelemahan (dilihat dari nilai rating terkecil) berada pada W1, yaitu jumlah SDM (karyawan). Kelemahan ini harus sangat diperhatikan oleh PT. Primavista Solusi apabila jika tidak ingin mengalami kegagalan. 


\section{Tahap Pencocokan (Matriks Grand Strategy dan Matriks SWOT)}

\section{Matriks Grand Strategy}

Untuk mendapatkan letak kuadrannya, ditentukan dengan menghitung selisih total score antara peluang dengan ancaman dan kekuatan dengan kelemahan. Hasil selisih tersebut diperlihatkan pada Tabel 3.

Tabel 3. Selisih Total Score Faktor Eksternal dan Faktor Internal

\begin{tabular}{|c|r|c|r|}
\hline PELUANG & 1.860 & KEKUATAN & 1.881 \\
\hline ANCAMAN & 1.255 & KELEMAHAN & 0.774 \\
\hline SELISIH & $\mathbf{0 . 6 0 5}$ & SELISIH & $\mathbf{1 . 1 0 7}$ \\
\hline
\end{tabular}

Berdasarkan Tabel diatas, didapat selisih score antara peluang dengan ancaman dan kekuatan dengan kelemahan bernilai positif. Untuk faktor eksternal didapat nilai sebesar +0.605 dan untuk faktor internal didapat nilai sebesar + 1.107. Berdasarkan nilai tersebut, dapat disimpulkan bahwa kondisi perusahaan berada dalam kuadran I. Posisi perusahaan yang berada di kuadran I berdasarkan perhitungan total score diperlihatkan pada gambar 1.

Perusahaan yang berada di dalam kuadran I matriks Grand Strategy memiliki posisi strategis yang sempurna (David, 2009). Pada kuadran I ini, disajikan beberapa alternatif strategi, yaitu pengembangan pasar, penetrasi pasar, pengembangan produk, integrasi ke depan, integrasi ke belakang, integrasi horizontal, dan diversifikasi terkait.

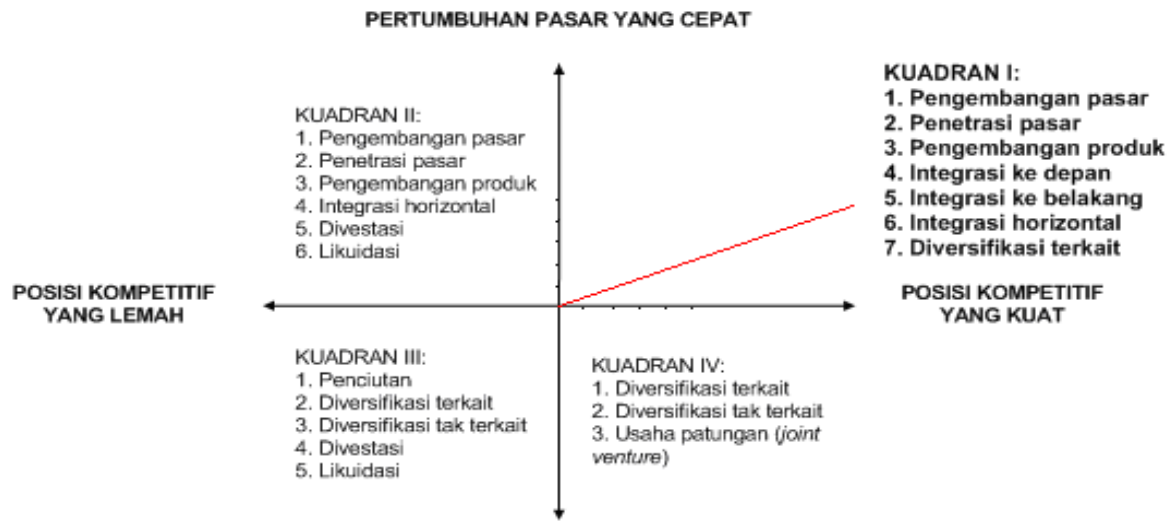

PERTUMBUHAN PASAR YANG LAMBAT

\section{Gambar 1 Posisi PT. PRIMAVISTA SOLUSI dalam Matriks Grand Strategy}

Perusahaan yang berada pada kuadran I matriks grand strategy memiliki posisi strategis yang sempurna. Dapat dikatakan PT. PRIMAVISTA SOLUSI berada pada posisi yang sempurna. Untuk perusahaan yang terletak pada kuadran I, konsentrasi pada pasar (penetrasi pasar dan pengembangan pasar) dan produk (pengembangan produk) merupakan strategi yang sesuai. 


\section{Matriks SWOT}

Matriks SWOT merupakan salah satu matriks tahap pencocokan dalam penelitian ini. Matriks SWOT adalah salah satu alat pencocokan untuk mengembangkan empat jenis strategi, yaitu strategi SO (kekuatan-peluang), strategi WO (kelemahan-peluang), strategi ST (kekuatan-ancaman), dan strategi WT (kelemahan-ancaman). Pada tahap ini dilakukan pencocokan antara faktorfaktor eksternal dengan faktor-faktor internal. ks SWOT ditampilkan pada Gambar 2.

\begin{tabular}{|c|c|c|}
\hline $\begin{array}{l}\text { Faktor } \\
\text { Eksternal }\end{array}$ & $\begin{array}{l}\text { Kekuatan - Strength (S) } \\
\text { 1. Kemampuan karyawan } \\
\text { mengembangkan produk } \\
\text { 2. Pengetahuan karyawan terhadap } \\
\text { produk yang dijual } \\
\text { 3. Motivasi karyawan } \\
\text { 4. Produktivitas karyawan } \\
\text { 5. Kedisiplinan karyawan terhadap } \\
\text { peraturan perusahaan } \\
\text { 6. Ambisi perusahaan } \\
\text { 7. Pengembangan solusi in-house } \\
\text { 8. Produk-produk yang ditawarkan } \\
\text { oleh perusahaan } \\
\text { 9. Rate bisnis yang bersaing } \\
\text { dengan kompetitor } \\
\text { 10. Lokasi servis di kota-kota di } \\
\text { Indonesia }\end{array}$ & $\begin{array}{l}\text { Kelemahan - Weakness (W) } \\
\text { 1. Jumlah Sumber Daya Manusia } \\
\text { (karyawan) } \\
\text { 2. Kualitas servis yang diberikan } \\
\text { kepada pelanggan } \\
\text { 3. Kualitas aplikasi yang dihasilkan } \\
\text { 4. Customized solution } \\
\text { 5. Kesejahteraan karyawan } \\
\text { 6. Kelengkapan peralatan operasional } \\
\text { untuk karyawan } \\
\text { 7. Sistem manajemen perusahaan } \\
\text { 8. Komunikasi antar divisi } \\
\text { 9. Sistem dokumentasi produk }\end{array}$ \\
\hline 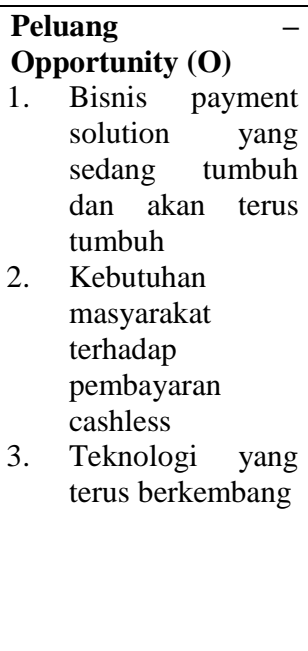 & $\begin{array}{l}\text { Strategi SO: } \\
\text { 1. Meningkatkan penawaran solusi } \\
\text { atau produk baru kepada } \\
\text { pelanggan (S2, S3, S4, S8, S9, } \\
\text { O1, O2, O3) } \\
\text { 2. Rajin mengkuti tender (S1, S2, } \\
\text { S3, S4, S7, S8, S9, S10, O1, O2, } \\
\text { O3) } \\
\text { 3. Membentuk tim call centre 24 } \\
\text { jam untuk melayani merchant } \\
\text { (S3, S4, S6, S10, O2) } \\
\text { 4. Menawarkan produk-produk } \\
\text { dan solusi kepada bank-bank } \\
\text { yang belum menjadi pelanggan } \\
\text { (S1, S2, S3, S4, S6, S7, S8, S9, } \\
\text { S10, O1, O2, O3) }\end{array}$ & $\begin{array}{c}\text { Strategi WO: } \\
\text { 1. Penambahan jumlah karyawan, } \\
\text { terutama bagian engineer (W1, O1, } \\
\text { O2, O3) } \\
\text { 2. Membentuk tim khusus untuk } \\
\text { menangani keluhan pelanggan, } \\
\text { sehingga keluhan pelanggan dapat } \\
\text { segera ditangani (W2, O2) } \\
\text { 3. Membentuk tim QA untuk menguji } \\
\text { setiap aplikasi yang dikembangkan } \\
\text { agar dapat berjalan baik sesuai } \\
\text { permintaan pelanggan (W3, O3) } \\
\text { Membuat SOP baru yang sesuai } \\
\text { dengan perkembangan bisnis serta } \\
\text { membuat kebijakan-kebijakan baru } \\
\text { kearah perbaikaan sistem } \\
\text { manajemen perusahaan (W5, W6, } \\
\text { W7, O1, O2, O3) }\end{array}$ \\
\hline
\end{tabular}




\begin{tabular}{|c|c|c|}
\hline $\begin{array}{l}\text { Ancaman - Threats } \\
\text { (T) } \\
\text { 1. Pesaing yang } \\
\text { bergerak dibidang } \\
\text { yang sama } \\
\text { 2. Regulasi } \\
\text { pemerintah } \\
\text { (pajak, bea cukai, } \\
\text { dsb) } \\
\text { 3. Bencana alam } \\
\text { 4. } \\
\text { Krisis ekonomi }\end{array}$ & $\begin{array}{l}\text { Strategi ST: } \\
\text { 1. } \\
\text { Membentuk tim R\&D untuk } \\
\text { membuat inovasi-inovasi baru } \\
\text { agar solusi yang ditawarkan } \\
\text { selalu selangkah lebih maju (S1, } \\
\text { S3, S4, S6, S7, T1) } \\
\text { 2. Mengasuransikan seluruh asset } \\
\text { perusahaan (S6, T3) } \\
\text { 3. Mengikuti aturan-aturan yang } \\
\text { diterapkan pemerintah (S6, T2) }\end{array}$ & 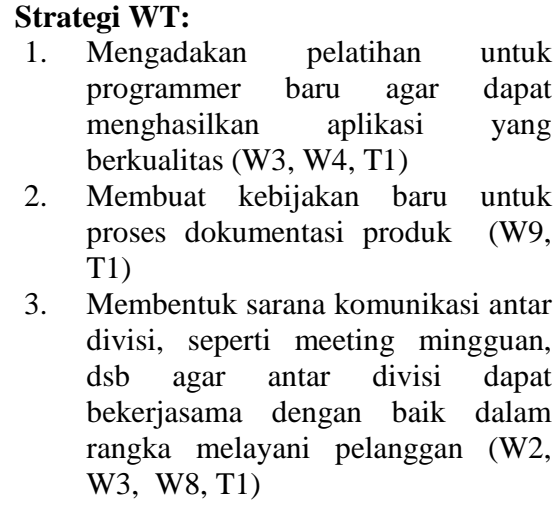 \\
\hline
\end{tabular}

\section{Gambar 2. Matriks SWOT}

\section{Tahap Keputusan}

Berdasarkan tahap pencocokan (matching stage), terpilih tiga alternatif strategi yang dianggap sesuai dengan kondisi PT. Primavista Solusi, yaitu penetrasi pasar, pengembangan pasar, dan pengembangan produk. Tahap selanjutnya adalah tahap keputusan (decision stage), dimana pada tahap ini akan dipilih alternatif strategi yang paling sesuai dengan perusahaan.

Untuk mendapatkan keputusan ini, harus diketahui alternatif strategi mana yang memiliki tingkat kepentingan lebih penting dibandingkan dengan alternatif strategi lainnya. Untuk mengetahuinya diperlukan suatu perbandingan berpasangan, dimana setiap alternatif strategi akan dipasangkan dengan menggunakan kuesioner skala 1-9. Proses pengisian kuesioner ini dilakukan oleh Bapak Rudy Khowara selaku Presiden Direktur PT. Primavista Solusi. Setelah proses perhitungan perbandingan berpasangan selesai dilakukan, jika nilai CR konsisten, dapat dilakukan pemberian peringkat alternatif strategi terpilih sesuai nilai bobotnya. Bobot paling besar diberi peringkat paling utama. Berdasarkan pengolahan data tahap keputusan, didapat peringkat alternatif strategi yang ditampilkan pada Tabel 4.

Tabel 4. Peringkat Strategi Terpilih

\begin{tabular}{|l|c|c|}
\hline \multicolumn{1}{|c|}{ Alternatif Strategi } & Bobot & Peringkat \\
\hline Pengembangan produk & 0.4561 & 1 \\
\hline Pengembangan Pasar & 0.4561 & 2 \\
\hline Penetrasi Pasar & 0.0877 & 3 \\
\hline
\end{tabular}

Merujuk dari Tabel 3 diatas, alternatif strategi yang sesuai dengan kondisi PT. PRIMAVISTA SOLUSI saat ini adalah strategi pengembangan produk sebagai peringkat pertama, strategi pengembangan pasar sebagai peringkat kedua, dan strategi penetrasi pasar sebagai peringkat terakhir. 


\section{E. SIMPULAN}

Berdasarkan formulasi strategi yang telah dilakukan, terdapat 3 alternatif strategi yang akan diusulkan kepada PT. Primavista Solusi. Namun, yang paling utama adalah strategi pengembangan produk dan pengembangan pasar. Hal tersebut berdasarkan pada nilai bobot yang diperoleh pada tahap pencocokan. Strategi ini bertujuan untuk mendapatkan target laba yang telah ditentukan perusahaan.

\section{DAFTAR PUSTAKA}

Adnyana, R., \& Darma, G. S. (2015). STRATEGI MARKETING MIX, YIELD MANAGEMENT, CUSTOMER SATISFACTION AND OCCUPANCY RATE . Jurnal Manajemen dan Bisnis , 98-121.

Andreani, F. (2007). EXPERIENTIAL MARKETING (SEBUAH PENDEKATAN PEMASARAN) . JURNAL MANAJEMEN PEMASARAN , $1-8$.

Baroto, T., \& Purbohadiningrat, C. (2014). ANALISIS STRATEGI PENGEMBANGAN BISNIS PPOB KIPO MENGGUNAKAN ANALISIS SWOT DAN QSPM. Jurnal Teknik Industri , 88-102.

Bungin, B. (2007). Penelitian Kualitatif. Jakarta: Prenada Media Group.

David, F. R. (2009). Strategic Management. New Jersey: Prentice Hall.

Effendi, M., Setyorini, H., \& Santoso, I. (2016). Analisis Strategi Pemasaran Menggunakan Matriks SWOT dan QSPM (Studi Kasus: Restoran WS Soekarno Hatta Malang). Industria: Jurnal Teknologi dan Manajemen Agroindustri, 46-53.

Febrianti, O. V., \& K, M. S. (2014). Usulan Alternatif Strategi PT. X Menggunakan Quantitative Strategic Planning Matrix (QSPM) . E- Journal Graduate Unpar , 1-12.

FRETES, R. A., Santoso, P. B., Soenoko, R., \& Astuti, M. (2013). Strategi Perencanaan Dan Pengembangan Industri Pariwisata Dengan Menggunakan Metode Swot Dan Qspm (Studi Kasus Kecamatan LeitimurSelatan Kota Ambon). Jurnal Rekayasa Mesin , 109-108.

Putri, N. E., Astuti, R., \& Putri, S. A. (2016). PERENCANAAN STRATEGI PENGEMBANGAN RESTORAN MENGGUNAKAN ANALISIS SWOT DAN METODE QSPM (QUANTITATIVE STRATEGIC PLANNING MATRIKS) (STUDI KASUS RESTORAN BIG BURGER MALANG) . Jurnal Industria , 93-106.

Ramadhan, A., \& Sofiyah, F. R. (2008). Analisis SWOT sebagai landasan dalam menentukan strategi pemasaran ( studi McDonald's Ring Road ). Sistem Informasi . 
Rangkuti, F. (2009). Analisis SWOT Teknik Membedah Kasus Bisnis, Reorientasi Konsep Perencanaan Strategis untuk Menghadapi Abad 21. Jakarta: Gramedia Pustaka Utama.

Suci, R. P. (2009). Peningkatan Kinerja Melalui Orientasi Kewirausahaan, Kemampuan Manajemen, dan Strategi Bisnis (Studi pada Industri Kecil Menengah Bordir di Jawa Timur). JURNAL MANAJEMEN DAN KEWIRAUSAHAAN , 46-58.

Sugianto, C. A., \& Hongdiyanto, C. (2017). PERUMUSAN STRATEGI PEMASARAN MENGGUNAKAN METODE QSPM PADA BISNIS SAMBAL NOESANTARA . PERFORMA: Jurnal Manajemen dan StartUp Bisnis , 106-115.

Widianti, T., \& Damayanti, S. (2015). ANALISIS SWOT: STRATEGI PENGEMBANGAN KELOMPOK PENELITIAN . AMTEQ , 250-260.

Yin, K. R. (1996). Case Study Research Design and Methods. Jakarta: PT Raja Grafindo Persada. 